\title{
Chapter 5 \\ Who Is an Immigrant and Who \\ Requires Integration? Categorizing \\ in European Policies
}

\author{
Liza Mügge and Marleen van der Haar
}

\section{Introduction}

The formulation of immigration and integration policies is indispensably tied to the naming of immigrants, thereby differentiating between them. Categories form the backbone of policies, as they formally define (i) who is a wanted and who is an unwanted immigrant and (ii) who requires integration and who does not. "Immigrants" are far from homogeneous. They differ in characteristics such as migration motives (e.g., for work, political asylum, or family reunification), type of homeland (e.g., Western versus non-Western), and gender and ethnicity. Consequently, some immigrants are considered part of an intractable policy issue (Rein and Schön 1977; Schön and Rein 1994), whereas others are not. Whether a group is problematized or targeted as in need of integration depends on the combination of characteristics and statuses attributed to it. Such characteristics and statuses provide the basis of categories that define which immigration and integration policies a group is subjected to. For instance, integration policies tend to frame ethnic minority women, especially Muslims, as victims, while their male spouses and family members may be regarded as a threat to the state's ideals of gender equality since they are presumed to oppress

\footnotetext{
An earlier version of this chapter was presented at the workshop 'Power, Privilege and Disadvantage: Intersecting Gender and Diversity Studies in the Politics of (In)equality’ held 11-13 June 2014 in Maastricht. We thank the organizers of that workshop as well as Sara de Jong, Petra Debusscher, Blanca Garcés-Mascareñas, and Rinus Penninx for their comments on previous drafts.

L. Mügge

University of Amsterdam, Amsterdam, The Netherlands

e-mail: L.M.Mugge@uva.nl

M. van der Haar $(\bowtie)$

Institute for Management Research, Radboud University Nijmegen,

Nijmegen, The Netherlands

e-mail: m.vanderhaar@fm.ru.nl
} 
women (Bracke 2011; Roggeband and Verloo 2007). Such a framing leads to different policy outcomes for different groups of immigrants. Emancipation is generally seen as the main vehicle for the integration of Muslim women, while integration of Muslim men tends to focus on surveillance and control (Razack 2004).

This chapter draws on a literature review to examine the implications of categorization for immigration and integration trajectories. It examines how categories formalized in laws and regulations construct explicit as well as implicit target groups. For policy purposes, formal target groups tend to be treated as mutually exclusive (Yanow 2003). However, policies implicitly differentiate within target groups as well, for instance, along lines of religion and class (see also Schrover and Moloney 2013, 255). This chapter is guided by three questions. First, how do policies construct categorizations? Second, who do policies target explicitly, and who do they target implicitly? Third, under what conditions do policy categories (e.g., the groups that are considered problematic and "in need of integration") and terms (e.g., guest workers, allochthones, illegals, and asylum seekers) unintendedly render stereotypes, prejudices, and potential discrimination? The first section outlines theoretical perspectives on categories in policymaking. The second section analyses who is targeted explicitly and who is targeted implicitly by immigration and integration policies. In particular, it looks at the two main tracks of European citizens and third-country nationals (TCNs). Although policymaking — and therefore the use of categories-takes place at multiple levels that sometimes clash (e.g., rejected asylum seekers may be categorized as "unwanted" at the national level, but at the same time be accommodated at the local level), this chapter concentrates on the literature addressing the supranational and national levels.

\section{The Study of Categories and Its Relevance for Policymaking}

Categories are central organizing structures in all human societies (Hancock 2007, 64). They are key in attributing sameness and difference (Stone 2002, 308), based on a combination of 'achieved and ascribed traits' (Massey 2007, 1). Achieved characteristics are acquired in the course of living (e.g., being a member of a particular income class or a university graduate), while ascribed characteristics are set at birth (e.g., age and sex) (ibid.).

The study of categories is well developed in sociology and public policy. Gender studies and migration and ethnic studies focus on categories in their critical assessments of processes of exclusion and discrimination of women, migrants, and ethnic minorities. In doing so, scholars in these fields examine social stratification, referring to 'the unequal distribution of people across social categories that are characterized by differential access to scarce resources' (ibid.). These resources may be material (e.g., wealth), symbolic (e.g., social standing), or emotional (e.g., love). Stratification systems, Massey (2007) argues, order people vertically from a top to

a bottom. A society's degree of stratification is typically measured in terms of inequality, 'which assesses the degree of variability in the dispersion of people among ranked social categories' (ibid., 2). 
Stratification can be traced in two powerful mechanisms: 'the allocation of people into social categories, and the institutionalization practices that allocate resources unequally across these categories' (ibid.:, 5-6). These mechanisms produce categorical inequality, which is 'a pattern of social stratification that is remarkably "durable" in the sense that it is reproduced across time and generations' (Tilly 1998 cited by Massey 2007, 6). Stereotypes evolving from categorization are usually produced by those located at the top of the stratification system, namely, the people who control the most resources. For instance, whites in the USA have perpetuated negative stereotypes of African-Americans as unintelligent, hypersexual, and violent (Massey 2007, 15). Individual members of the stereotyped out-group tend to experience discrimination and exclusion over centuries (ibid.). Categorical mechanisms are thus deeply embedded within both the infrastructure of social institutions and cultural practices (ibid., xvi). As a result, categorical distinctions affect not only formal public settings, but also private life (ibid., 7).

States and policymakers use categories to describe social phenomena and turn them into policy problems on which they can intervene (Yanow 2003). Categories in this sense can be considered framing devices, with a frame defined as an 'organizing principle that transforms fragmentary or incidental information into a structured and meaningful problem, in which a solution is implicitly or explicitly included' (Verloo 2005, 20). Categories reflect social realities, but at the same time construct reality (Yanow 2003). State-defined categories used in policymaking may construct, implicitly or explicitly, ethnicized, gendered, or classed target groups. For instance, as a result of labour and postcolonial migration, the Netherlands government identified among others Turks, Moroccans, Surinamese, and Antilleans as a categorical target group and developed specific integration policies for them. Despite the internal ethnic, racial, and religious diversity within this group, these policies reflected reality at a certain point in time as immigrants started to organize themselves along the categorical units of Dutch integration policy. However, the naming of these groups also resulted in the monitoring of them in official statistics. As a result, their children - the so-called "second generation"-are also categorized on the basis of the country of birth of their parents. In this way their identity is attributed.

Categories are crucial for the formulation of policies, and they are a central point of departure in studies of inequality. Categorical inequality may result when those in power enact policies that give certain groups more access to resources than others and systematically channel social and cultural capital to particular categories of people (Massey 2007, 23). In the context of migration and integration, categories are used to define target groups for policies. In some countries such categories are ascribed, while in others they are based on "self-identification". We described above the Netherlands' use of categories based on the birth country of immigrants or their parents. In the UK people are asked to themselves choose between a number of broad race-based categories and subcategories based on ethnicity. ${ }^{1}$ Censuses are a powerful tool for states to collect information about the "origin" and mobility of their residents. The European Union (EU) 2008 census regulation requires member

\footnotetext{
${ }^{1}$ www.ons.gov.uk/ons/guide-method/measuring-equality/equality/index.html, accessed 13 July 2014.
} 
states to collect information about residents' country of birth (distinguishing between EU and non-EU member states) and country of citizenship (EC 2011). This has enabled the EU to produce statistics about resident foreigners and foreign-born EU citizens. Although this may appear to be a neutral activity, state institutions may reorganize these data and allocate identities to residents that are not at all neutral. For instance, the Netherlands and Flemish (Belgium) governments have used the term "non-Western allochthon" to demarcate the target group for integration policies (Jacobs and Rea 2012; Yanow and Van der Haar 2013). In the Netherlands, the term is officially reserved for persons who themselves or at least one of their parents were born in Turkey, Africa, Latin America, or Asia. In practice, this means that especially migrants from Muslim countries are considered the problem category (Groenendijk 2011, 22; see also Yanow and Van der Haar 2013). The concept of allochthon first appeared in a 1971 report on post-Second World War migration (Verwey-Jonker 1971). The term gained ground in 1984 when the Dutch Central Bureau of Statistics started to monitor the lives of migrants and their children. The term appears in policy discussions from 1989 onwards (WRR 1989). The taxonomy it implies, and especially the distinction between Western and non-Western allochthones, creates a hierarchy between individuals based on their country of birth (Yanow and Van der Haar 2013). Much analysis of categories has been inspired by the interpretive study of what is considered to be the problem (diagnosis) and the proposed solution (Verloo 2005). Studying the diagnostic part of policy texts is a useful way to uncover why particular groups are problematized and singled out as target groups, while others are not. The target group is usually formulated in reference to existing social categories, such as race/ethnicity, religion, class, and gender. The proposed solution then is captured in policymaking. To understand who are targeted explicitly and implicitly by immigration and integration policies the following section examines what we term the "policy chain", which determines which policies immigrants are subjected to from the moment of their arrival.

\section{Explicit Target Groups and Implicit Hierarchies in the Policy Chain}

Problematizing the mobility of persons is inherent to the idea of the nation state that presupposes unity of territory, state, and citizens (Geiger 2013, 17). European nation states and EU institutions have built systems to regulate who can enter their respective territories and under what conditions. Increasingly, not only immigration but also the integration of migrants is a policy issue. This section discusses the legal categories used to define mobile persons and the effect of these categories in directing a migrant's route in the policy chain (Fig. 5.1). The starting point is a categorization by the EU based on a person's country of origin. Is the person in question a citizen of an EU member state or a TCN. This dichotomy leads to divergent paths determining whether or not migrants do eventually become the subject of integration policy and whether they will gain access to social, political, and economic rights. 


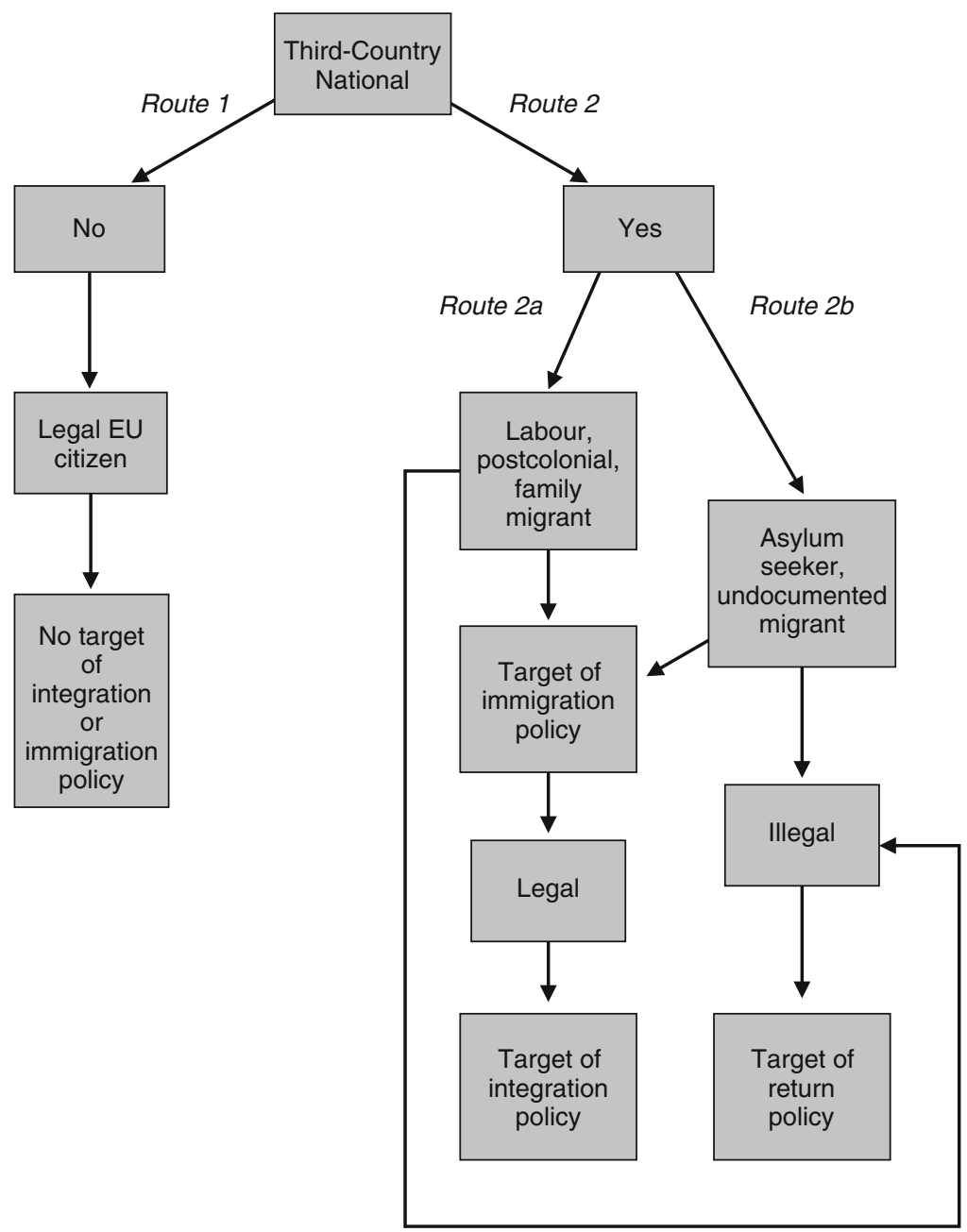

Fig. 5.1 Migrants' routes in the categorical policy chain (Source: Authors)

\section{Route 1: EU Citizens}

The first step in the policy chain establishes whether a migrant is a member-state national or a TCN (Rea et al. 2011, 10). The legal term "TCN" is based on nationality and residence status, not on ethnic origin or culture (Groenendijk 2011, 34). Introduction of the right to free movement of EU citizens (based on the 1985 Schengen Agreement and 1990 Schengen Convention) and the harmonization of migration law and policy (via the Amsterdam Treaty, which entered into force in 1999) had substantial impact on the distinction between migrants who are considered in need of integration and those who are not. Yet, although these agreements 
reduced the legal distance between national citizens and member-state nationals (ibid.), this does not mean that all Europeans gained equal status.

EU policies start from the assumption that EU citizens, when moving to another member state as Europeans, are integrated by default. Consequently, integration policies and facilities have been designed and implemented for TCNs only. Nonetheless, policy debates, and in some cases policies, at the national level and even more so at the local level do distinguish between EU citizens. For instance, migrant workers from relatively new EU members, such as Poland, Romania, and Bulgaria, are to be excluded from integration policies according to EU definitions, but their lack of "integration" has nonetheless been criticized in public and political fora. Migrants from the newer EU member states often face highly nationalized demands for integration, including language competence requirements and culturalized and moralized citizenship tests (Favell 2013, 5). Prior to Britain's lifting of restrictions on migrants from Bulgaria and Romania in January 2014, UK politicians-in direct opposition to the EU's integration definition - proposed a cap on social services for European migrants. ${ }^{2}$

In fact, tensions may result from differences in policy aims between the EU and its member states. A striking example is the treatment of the Roma from Bulgaria and Romania in France. Whereas EU institutions have, in the context of enlargement policy, continuously argued for measures to promote the social inclusion of the Roma (Parker 2012, 476), this was disregarded by the French authorities. Following riots and clashes between Roma and the French police in July 2010, President Sarkozy ordered half of the country's 539 Roma camps to be cleared to restore 'the republican order' (ibid., 478). Shortly after, the French government expelled more than 1,000 camp inhabitants, sending them back to their countries of origin. ${ }^{3}$ These actions led to a direct confrontation with the European Commission, which interpreted the French actions as an existential threat to the European peace project. The EU warned France that it would pursue infringement procedures. The Commission's proceedings against France hinged on

\begin{abstract}
the fact that France had not fully transposed aspects of the 2004 Directive on free movement into its national legislation. This had enabled the country to avoid deploying various safeguards specified within this Directive in order to protect EU citizens targeted for removal either on the basis of their being a 'threat to public order or security' or on the basis of their 'insufficient [economic] means' (ibid., 479-480).
\end{abstract}

This example illustrates the clear hierarchy between EU citizens from the West and those from Eastern Europe. Favell (2013) argues that next to familiar targets, such as Muslims and undocumented Africans, currently Eastern Europeans (e.g., Poles and Romanians) and Southern Europeans (Greek, Portuguese, and potentially highly qualified Spaniards and Italians) are included in what he calls the antiimmigration tide. Free movement and equal treatment may be guaranteed in legal

\footnotetext{
${ }^{2}$ www.spiegel.de/international/europe/western-europe-fearful-of-roma-immigrants-from-romania-and-bulgaria-a-884760.html, accessed on 8 June 2014.

${ }^{3}$ www.migrationpolicy.org/article/frances-expulsion-roma-migrants-test-case-europe, accessed on 13 July 2014.
} 
and political terms, but it is not a 'sociological reality' (ibid., 4). Indeed, 'not all citizens are equal and some passports are better than others'. Hierarchies between citizens lead to a 'new system of global economic stratification' (Castles 2004, 223).

\section{Route 2: Third-Country Nationals}

TCNs are categorized on the basis of their admission labels, such as labour migrants, asylum seekers, family migrants, refugees, and postcolonial migrants (Schrover and Moloney 2013, 257). Labour migrants are characterized in economic terms. They migrate for reason of employment, either on a temporary or permanent basis. Family migrants come to form a family (marriage migration) or to be reunited with family members (family reunification). This type of migration is highly and explicitly feminized (Bonjour and De Hart 2013). Postcolonial and colonial migrants are those originating from countries formerly colonized by the country of destination. In many cases, they have — or had — a legal right to settle in European countries (Hampshire 2013, 18). Policymakers use these categorizations as mutually exclusive groups. But in reality, these broad classifications overlap. People may move between categories (ibid., 257) or they may use the policy labels available for their migration project. For instance, many of the guest workers who left Greece, Spain, and Portugal in the 1960s and early 1970s had political motives to flee the regimes of colonel Papadopoulos and Makarezos, Franco, and Salazar, respectively. Applying for asylum in North and West European countries was cumbersome and risky. In those days it was easier to apply for a residence permit for work.

Many scholars point to the disproportional problematization of non-European immigrants (Rea et al. 2011; Favell 2013; Schmidtke 2012). Schmidtke (2012, 32) argues that the term TCN creates a non-European "other" by which the EU reproduces a "hiatus between the wanted, highly-qualified, ideally Western migrants, and the unwanted ones from the non-European world'. The distinction made between wanted and un-wanted follows a 'utilitarian logic' of the country's economic competitiveness (ibid.). The difference between wanted and unwanted TCN immigrants comes clearly to the fore through visa procedures. Rules of visa application make use of so-called "positive" and "negative" lists to distinguish between TCNs that need a visa to travel to the EU Schengen area and those who do not (Groenendijk 2011, 24). Central databases have been created to collect information about nonnationals, especially since the 2004 and 2007 directives on legal migration. The introduction of these immigration databases ${ }^{4}$ is legitimated as a security and safety

\footnotetext{
${ }^{4}$ Groenendijk $(2011,33-34)$ refers to three databases. The first, the Schengen Information System (SIS; SIS-II is the new version which includes the possibility of using biometrics) enables exchange of data about suspected criminals, people who may not have the right to enter the EU, missing persons, and stolen, misappropriated, or missing property. Second, EURODAC is a system for comparing fingerprints of asylum seekers and some illegal migrants. Third the Visa Information System (VIS) enables Schengen countries to exchange visa data.
} 
measure linked to the political context of the fight against terrorism, other serious crime, and illegal immigration (ibid., 33). The lists are said to be based on criteria such as potential security risk, illegal immigration, and economic relations. The result is that the "positive" list consists of "rich countries and countries in Europe and the Americas with predominantly white populations' (ibid.). Besides the implied distinction based on class and race/ethnicity, the lists also mark a religious watershed, as in practice they also distinguish between Muslim and Christian populations (ibid.).

\section{Route 2a: Legal Immigrants and Target of Integration Policy}

The group of immigrants that is allowed formal access becomes legal and a target of integration policy. Particular measures in current integration and immigration policy practice appear to spotlight female migrants (on women marriage migrants, see Bonjour and De Hart 2013; on gender inequality as an ethnicized problem see Roggeband and Verloo 2007; Prins and Saharso 2008), while migrant masculinity is often problematized (Van der Haar 2013; Scheibelhofer 2012). Bonjour and De Hart (2013) suggest that the Netherlands' policymaking on marriage migration is shaped by the idea of transnational marriages being fraudulent and forced, and (Muslim) migrant women being the victims of these practices. Scheibelhofer (2012) sets out how the image of an "archaic migrant masculinity" is used to legitimate restrictive migration laws in Austria: the human capital, norms, and values of migrant men have become criteria for their classification as wanted or unwanted. The general discourse that becomes clear from the abovementioned studies is that women migrants need to be protected by the "receiving state", whereas migrant men mainly need to be controlled. In these cases, "marked identities" (Yanow 2003) again based on homogenized social categories like race/ethnicity, gender, class, and religion (often replicated in research as static analytical categories) are reproduced. Furthermore, negative and pejorative assumptions about groups are especially highlighted, resulting in a singling out of particular immigrants to be targeted by particular measures.

Religion and most certainly Islam is another important factor in prioritizing women migrants as a target group in policies. These women are associated with problems ranging from honour related violence, forced and arranged marriages, genital mutilation, and domestic violence to low labour market participation. Migrant women with a Muslim background are portrayed as victims of patriarchal cultures informed by Islam. As many European states perceive themselves as liberal, these women are targeted in family-related migration policies and integration policies that aim to transmit norms of gender equality (see Bonjour and De Hart 2013 on the Netherlands; for a comparative study on seven EU countries, see Kofman et al. 2013). But again, assumptions about class, in the form of low education and backwardness, are used to legitimize restrictions in family migration and strict measures of cultural assimilation into the destination society through state 
integration policies. Razack (2004), for example, argues that Norway's culturalist approach to forced marriages enables the stigmatization and surveillance of Muslim communities and feeds the idea of European superiority. The assumed causalities in the diagnoses underlying policy issues may thus have highly exclusionary consequences.

Critical scholars have stressed the risk of homogenizing, and hereby essentializing, identities in policy and research (e.g., Rath 1991; Ghorashi 2006; Schinkel 2007; Bertossi and Duyvendak 2012; Jacobs and Rea 2012). The main concern is that categories defined in policies at the supranational or state level produce or reinforce stereotypes that foster prejudices and potential discrimination. The following examples show how the dichotomy allochthon and autochthon and subcategories in the Netherlands and Flanders have produced durable stereotypes. These stereotypes are products of the formal policy chain and-as Massey (2007) reminds us-affect private life, but are increasingly contested by the children and grandchildren of immigrants.

"Allochthon" and its counterpart "autochthon" have taken on a for-granted character in Dutch and Flemish politics, administration, and society (Jacobs and Rea 2012; Van der Haar and Yanow 2011; De Zwart 2012). However, changes are visible at the local level, at the insistence of a new generation of "allochthones". The city of Ghent, for instance, declared the twin concepts "dead and buried" on the international day against racism (Severs 2014). This marked the official end of the allochthon-autochthon distinction in the administrative jargon of the municipality.

Since the 1980s, the Netherlands has developed an international reputation as a multicultural society due in part to its efforts to promote integration of ethnic minorities while also enabling them to maintain their culture. This resulted in groupspecific policies for the largest immigrant groups, among them Turks, Moroccans, Surinamese, Antilleans, Moluccans, and Southern Europeans (Vermeulen and Penninx 2000). Both the general term "ethnic minorities" and its various subcategories became deeply rooted in daily life, though they have not gone uncontested by substantial numbers of the people labelled in these terms. For instance, during a local election rally in March 2014, Geert Wilders, the leader of the Dutch populist right-wing party PVV, asked the gathered crowd whether there should be "fewer Moroccans" in the Netherlands. In an indignant response, Dutch citizens of Moroccan descent started a Twitter campaign under the hashtag "BornHere". They posted "selfies" defiantly showing their Dutch passports. ${ }^{5}$ In the ensuing days, Dutch politicians, organizational leaders, comedians, and individual citizens of Moroccan descent mobilized and filed thousands of discrimination complaints against Wilders. ${ }^{6}$ This attracted wide support of the established white political elite in praise of the outspoken Moroccan-Dutch activism. This activism takes on even greater symbolic weight in light of Morocco's citizenship law: Moroccans cannot renounce their Moroccan passport. The Dutch-Moroccan activists thus made a

\footnotetext{
${ }^{5}$ See www.economist.com/blogs/charlemagne/2014/03/dutch-far-right, accessed on 4 April 2014.

${ }^{6}$ See www.theguardian.com/world/2014/mar/20/dutch-politician-geert-wilders-moroccans-outrage-pvv-party-anti-islam, accessed on 4 April 2014.
} 
public choice for the Netherlands. They were fed up with being seen as Moroccan. Ethnic minority students at academic institutions across Western countries, such as Harvard, Oxford, and the University of Amsterdam launched a similar campaign: "I too am [name of the university]." Here, ethnic minority students were portrayed holding handwritten signs quoting implicit or explicit discriminatory comments they experienced on a daily basis (e.g., on forced marriage, skin colour, and language skills). ${ }^{?}$

The message is clear: the children and grandchildren of immigrants represent a new generation of highly educated and eloquent citizens who no longer accept being seen as second-class citizens judged merely on their immigrant backgrounds. They are not different. The \#BornHere and "I too" campaigns point to the development of stereotypes based on assumptions of a poorly integrated first-generation immigrant who lived in a parallel society and aimed to return home as soon as possible. These are not stand-alone examples, but are part of a broader ethnic minority stance against being seen and treated as outsiders by the majority population, "even after two generations" (Andriessen et al. 2007, 107; Entzinger and Dourleijn 2008 cited by De Zwart 2012, 312).

\section{Route 2b: Legal Immigrants and Target of Return Policy}

Undocumented migration and the entry of asylum seekers are driven by forcessuch as transnational networks - that governments cannot control (Castles 2004, 205). Although the issue of asylum was actually an important incentive for the EU to harmonize migration-related policies (see Penninx and Scholten in this volume), it has proven difficult to address the root causes of migration, not least because of the different objectives of the various EU bodies and member states (Castles 2004, 223). Undocumented immigrants and asylum seekers who are not granted residence permits become the target of return policies. In many European states, unsuccessful asylum seekers may be transferred to "detention and removal centres" (on the UK see Sales 2002; on Sweden see Khosravi 2009); others become "illegals" trying to live their lives without formal papers. The EU deportation regime has received particular public attention regarding the position of women (as mothers) and children. In Norway, the UK, Sweden, Germany, and the Netherlands media have featured stories of children who have been sent "back"-sometimes forcibly (Fekete 2005). Scholars also point to an increasing proportion of asylum seekers being trafficked as a result of restrictive policies (Koser 2000). Here again, women and children are especially targeted in protective policies, for example, as a result of the 2000 United Nations Protocol to Suppress, Prevent and Punish Trafficking, Especially Women and Children (Hastie 2013).

Undocumented immigrants are vulnerable and caught in between different policy layers. Formally they are excluded from integration policies, but at the same

${ }^{7}$ See http://itooamuva.tumblr.com/, accessed on 15 April 2014. 
time many are informally incorporated by local institutions such as schools, churches, and associations (for an overview of literature on this category see Chauvin and Garcés-Mascareñas 2012). As Castles (2004, 223) argues, '[policies] that claim to exclude undocumented workers may often really be about allowing them in through side doors and back doors, so that they can more readily be exploited'. At the same time, expelled migrants are attracted by the demand for the flexible labour facilitated by the large informal economy in countries such as Greece (Fakiolas 2003).

The presence of undocumented migrants and opportunities for them to settle vary widely across European member states. Hellgren (2014) argues that undocumented migrants are more accommodated in Spain than in Sweden. Until 1 July 2013 undocumented migrants in Sweden had-in contrast to recognized asylum seekers-no right to basic healthcare and schooling for their children. This was amended under pressure of the United Nations, which criticized Sweden for violating human rights conventions (ibid., 1180). In Spain undocumented migrants are documented at the local level. They have the same access to schooling and, up to 2012, healthcare as anyone else (Garcés-Mascareñas 2012, 121, 209). Moreover, Spain has a larger informal population than Sweden. Undocumented migrants in the former fill a major "care gap", providing cheap labour in healthcare, childcare, and domestic services. While in Sweden undocumented migrants 'reflect a moral dilemma and challenge to the principles of the welfare state', in Spain 'the presence of individuals without permission to stay may not be problematic for any moral reasons, or by principle' (Hellgren 2014, 1184).

\section{Conclusion}

Categories form the backbone of policies. This chapter examined how categories are constructed in immigration and integration policies, alongside who policies target and in what ways categorizing may lead to stereotypes and exclusion. Processes of categorization both reflect reality and construct identities as they are understood by the ethnic majority. Categories furthermore determine the policy route migrants are subjected to upon their arrival. At the EU level the basic binary categorization is EU citizen versus TCN, and this defines who requires integration (TCNs) and who does not (EU citizens). Although European citizens are not formally subject to integration policy, Western European immigration countries do make implicit distinctions between migrants from "new" and "old" member states. In other, words, not all intra-European migrants are as equal in daily life as they are on paper. Migrants from the Eastern European member states are categorized differently. TCNs-i.e., migrants from outside the EU-form the general target group of EU integration policies as well as return and deportation measures. TCNs who are legal, or at least admitted, become the target of integration policies. Others become the object of increasingly exclusionary social policies and deportation. 
Hierarchies within the categories European citizens and TCNs produce implicit and sometimes explicit unequal treatment at the national and local levels. Some groups, such as Muslims, are more problematized than others, and hierarchies are often based on a combination of identity markers such as gender, class, and ethnicity. Hierarchies are bound to national contextual factors, such as the mode of categorization used (top-down or based on self-identification), the type of welfare state, the scope of certain types of immigration, and the extent to which immigrants are "needed" to fill gaps in the labour market. Categories create stereotypes that persist over generations, resulting in patterns of social stratification. Categories cannot be abandoned in policymaking, but to make policies more effective scholars and policymakers alike should be alert to their use, scope, and impact.

Open Access This chapter is distributed under the terms of the Creative Commons AttributionNoncommercial 2.5 License (http://creativecommons.org/licenses/by-nc/2.5/) which permits any noncommercial use, distribution, and reproduction in any medium, provided the original author(s) and source are credited.

The images or other third party material in this chapter are included in the work's Creative Commons license, unless indicated otherwise in the credit line; if such material is not included in the work's Creative Commons license and the respective action is not permitted by statutory regulation, users will need to obtain permission from the license holder to duplicate, adapt or reproduce the material.

\section{References}

Andriessen, I., Dagevos, J., Nievers, E., \& Boog, I. (2007). Discriminatiemonitor niet-westerse allochtonen op de arbeidsmarkt 2007. Den Haag/Rotterdam: Sociaal Cultureel Planbureau/ Art.1.

Bertossi, C., \& Duyvendak, J. W. (2012). National models of immigrant integration: The costs for comparative research. Comparative European Politics, 10(3), 237-247.

Bonjour, S., \& De Hart, B. (2013). A proper wife, a proper marriage: Constructions of "us" and "them" in Dutch migration policy. European Journal of Women's Studies, 20(1), 61-76.

Bracke, S. (2011). Subjects of debate: Secular and sexual exceptionalism, and Muslim women in the Netherlands. Feminist Review, 98(1), 28-46.

Castles, S. (2004). Why migration policies fail. Ethnic and Racial Studies, 27(2), 205-227.

Chauvin, S., \& Garcés-Mascareñas, B. (2012). Beyond informal citizenship: The new moral economy of migrant illegality. International Political Sociology, 6(3), 241-259.

De Zwart, F. (2012). Pitfalls of top-down identity designation: Ethno-statistics in the Netherlands. Comparative European Politics, 10(3), 301-318.

EC (European Commission). (2011). EU legislation on the 2011 population and housing censuses: Explanatory notes. Eurostat methodologies and working papers. Luxembourg: Publications Office of the European Union. http://ec.europa.eu/eurostat/documents/3859598/5916677/ KS-RA-11-006-EN.PDF/5bec0655-4a55-466d-9a00-fabe83d54649?version=1.0

Entzinger, H., \& Dourleijn, E. (2008). De lat steeds hoger: De leefwereld van jongeren in een multietnische stad. Assen: Van Gorcum.

Fakiolas, R. (2003). Regularising undocumented immigrants in Greece: Procedures and effects. Journal of Ethnic and Migration Studies, 29(3), 535-561.

Favell, A. (2013). The changing face of integration in a mobile Europe. www.adrianfavell.com/ CESweb.pdf. Accessed 30 Apr 2014. 
Fekete, L. (2005). The deportation machine: Europe, asylum and human rights. Race \& Class, 47(1), 64-78.

Garcés-Mascareñas, B. (2012). Labour migration in Malaysia and Spain: Markets, citizenship and rights. IMISCOE Research. Amsterdam: Amsterdam University Press.

Geiger, M. (2013). The transformation of migration politics: From migration control to disciplining mobility. In M. Geiger \& A. Pécoud (Eds.), Disciplining the transnational mobility of people (pp. 15-40). Houndmills: Pallgrave Macmillan.

Ghorashi, H. (2006). Paradoxen van culturele erkenning: Management van diversiteit in nieuw Nederland. Inaugural lecture. Amsterdam: Vrije Universiteit.

Groenendijk, K. (2011). Categorizing human beings in EU migration law. In S. Bonjour, A. Rea, \& D. Jacobs (Eds.), The others in Europe (pp. 21-36). Brussels: Editions de l'Université de Bruxelles.

Hampshire, J. (2013). The politics of immigration: Contradictions of the liberal state. Cambridge: Polity Press.

Hancock, A.-M. (2007). When multiplication doesn't equal quick addition: Examining intersectionality as a research paradigm. Perspectives on Politics, 5(1), 63-79.

Hastie, B. (2013). To protect and control: Anti-trafficking and the duality of disciplining mobility. In M. Geiger \& A. Pécoud (Eds.), Disciplining the transnational mobility of people (pp. 126144). Houndmills: Pallgrave Macmillan.

Hellgren, Z. (2014). Negotiating the boundaries of social membership: Undocumented migrant claims-making in Sweden and Spain. Journal of Ethnic and Migration Studies, 40(8), $1175-1191$.

Jacobs, D., \& Rea, A. (2012). "Allochthones" in the Netherlands and Belgium. International Migration, 50(6), 42-57.

Khosravi, S. (2009). Sweden: Detention and deportation of asylum seekers. Race \& Class, 50, $38-56$.

Kofman, E., Saharso, S., \& Vacchelli, E. (2013). Gendered perspectives on integration discourses and measures. International migration. doi: 10.1111/imig.12102. online first.

Koser, K. (2000). Asylum policies, trafficking and vulnerability. International Migration, 38(3), 91-111.

Massey, D. (2007). Categorically unequal: The American stratification system. New York: Russell Sage.

Parker, O. (2012). Roma and the politics of EU citizenship in France: Everyday security and resistance. Journal of Common Market Studies, 50(3), 475-491.

Prins, B., \& Saharso, S. (2008). In the spotlight: A blessing and a curse for immigrant women in the Netherlands. Ethnicities, 8(3), 365-384.

Rath, J. (1991). Minorisering: De sociale constructie van "etnische minderheden". Amsterdam: Socialistische Uitgeverij Amsterdam.

Razack, S. H. (2004). Imperilled Muslim men, dangerous Muslim men and civilized Europeans: Legal and social responses to forced marriages. Feminist Legal Studies, 12(3), 129-174.

Rea, A., Bonjour, S., \& Jacobs, D. (2011). Introduction. In S. Bonjour, A. Rea, \& D. Jacobs (Eds.), The others in Europe (pp. 7-19). Brussels: Editions de l'Université de Bruxelles.

Rein, M., \& Schön, D. A. (1977). Problem setting in policy research. In C. H. Weiss (Ed.), Using social research in public policy making (pp. 235-251). Lexington: Lexington Books.

Roggeband, C., \& Verloo, M. (2007). Dutch women are liberated, migrant women are a problem: The evolution of policy frames on gender and migration in the Netherlands, 1995-2005. Social Policy \& Administration, 41(3), 271-288.

Sales, R. (2002). The deserving and the undeserving? Refugees, asylum seekers and welfare in Britain. Critical Social Policy, 22(3), 456-478.

Scheibelhofer, P. (2012). From health check to Muslim test: The shifting politics of governing migrant masculinity. Journal of Intercultural Studies, 33(3), 319-332.

Schinkel, W. (2007). Denken in een tijd van sociale hypochondrie: Aanzet tot een theorie voorbij de maatschappij. Kampen: Klement. 
Schmidtke, O. (2012). Commodifying migration: Excluding migrants in Europe's emerging social model. The British Journal of Sociology, 63(1), 31-38.

Schön, D. A., \& Rein, M. (1994). Frame reflection: Toward the resolution of intractable policy controversies. New York: Basic Books.

Schrover, M., \& Moloney, D. M. (2013). Conclusion: Gender, migration and cross-categorical research. In M. Schrover \& D. M. Moloney (Eds.), Gender, migration and categorization: Making distinctions between migrants in Western countries, 1945-2010 (pp. 255-263). Amsterdam: IMISCOE Research. Amsterdam University Press.

Severs, E. (2014). The limits of categorical refurbishment: Ethnicization and racialization in the Flemish debate on how to denote "migrant" populations. Paper presented at the Politicologen Etmaal, 12-13 Jun, Maastricht.

Stone, D. (2002). Policy paradox: The art of political decision making. New York: W.W. Norton.

Van der Haar, M. (2013). Coming down from their thrones? Framing migrant men in Dutch politics. Women's Studies International Forum, 41(3), 215-222.

Van der Haar, M., \& Yanow, D. (2011). Allochtoon als metafoor en categorie: Over de handelingsimplicaties van beleidstaal. Beleid en Maatschappij, 2, 25-43.

Verloo, M. (2005). Mainstreaming gender equality in Europe: A critical frame analysis approach. Greek Review of Social Research, 117(B), 11-34.

Vermeulen, H., \& Penninx, R. (Eds.). (2000). Immigrant integration: The Dutch case. Amsterdam: Het Spinhuis.

Verwey-Jonker, H. (Ed.). (1971). Allochtonen in Nederland: Beschouwingen over de gerepatrieerden, Molukkers, Surinamers, Antillianen, Buitenlandse Werknemers, Chinezen, vluchtelingen, Buitenlandse studenten in onze samenleving. The Hague: Ministerie van Cultuur, Recreatie en Maatschappelijk Werk.

WRR. (1989). Allochtonenbeleid. The Hague: Scientific Council for Government Policy (WRR).

Yanow, D. (2003). Constructing race and ethnicity in America: Category-making in policy and administrative practices. Armonk: M. E. Sharpe.

Yanow, D., \& Van der Haar, M. (2013). People out of place: Allochthony and autochthony in Netherlands identity discourse. Metaphors and categories in action. Journal for International Relations and Development, 16(2), 227-261. 